\title{
The Priming Potential of Interferon Lambda-1 for Antiviral Defense in the Oral Mucosa
}

\author{
Yosuke Shikama $^{1,4}{ }$, Mie Kurosawa $^{1}$, Masae Furukawa ${ }^{1}$, Yasusei Kudo ${ }^{2}$, \\ Naozumi Ishimaru ${ }^{3}$ and Kenji Matsushita ${ }^{1}$
}

\begin{abstract}
Received 15 November 2021; accepted 8 January 2022
Abstract-The oral mucosa is one of the first lines of the innate host defense system against microbial invasion. Interferon (IFN) lambda-1 (IFN- $\lambda 1$ ), a type III IFN, exhibits type I IFN-like antiviral activity. In contrast to ubiquitously expressed type I IFN receptors, IFN- $\lambda$ receptor 1 (IFN- $\lambda \mathrm{R} 1$ ), which has higher affinity for type III IFNs than low-affinity interleukin (IL)-10 receptor 2, is mainly expressed on epithelial cells. Although IFN- $\lambda 1$ has been shown to exert antiviral effects in the respiratory tract, gastrointestinal tract, and skin, the regulation of type III IFN receptor expression and its functions in the oral mucosa remain unclear. We herein showed the expression of IFN- $\lambda \mathrm{R} 1$ in human gingival keratinocytes. The expression of IL-6, angiotensin-converting enzyme 2 (a critical molecule for severe acute respiratory syndrome coronavirus 2 infection), and IL-8 in human primary gingival keratinocytes (HGK) were significantly higher following treatments with either type I IFN (IFN- $\beta$ ) or type II IFN (IFN- $\gamma$ ) than with IFN- $\lambda 1$. However, the IFN- $\lambda 1$ treatment strongly induced toll-like receptor (TLR) 3 and retinoic acid-inducible gene I (RIG-I), which mainly recognize viral nucleic acids, via the STAT1-mediated pathway. Furthermore, a stimulation with a RIG-I or TLR3 agonist promoted the production of IL-6, IL-8, and IFN- $\lambda$ in HGK, which was significantly enhanced by a pretreatment with IFN$\lambda 1$. These results suggest that IFN $-\lambda 1$ may contribute to the activation of innate immune responses to oral viral infections by up-regulating the expression of RIG-I and TLR3 and priming their functions in keratinocytes.
\end{abstract}

KEY WORDS: keratinocyte; pattern recognition receptors; interferons; oral mucosa; innate immunity.

${ }^{1}$ Department of Oral Disease Research, National Center for Geriatrics and Gerontology, 7-430 Morioka-cho, Obu 474-8511, Japan

${ }^{2}$ Department of Oral Bioscience, Tokushima University Graduate

School of Biomedical Sciences, 3-18-15 Kuramoto-cho,

Tokushima 770-8504, Japan

${ }^{3}$ Department of Oral Molecular Pathology, Tokushima

University Graduate School of Biomedical Sciences, 3-18-15

Kuramoto-cho, Tokushima 770-8504, Japan

${ }^{4}$ To whom correspondence should be addressed at Department

of Oral Disease Research, National Center for Geriatrics and Gerontology, 7-430 Morioka-cho, Obu, 474-8511, Japan. Email: shikama@ncgg.go.jp

\section{INTRODUCTION}

Interferon (IFN)- $\lambda 1$, a recently discovered cytokine in the type III IFN family compared with the other IFN families, exhibits antiviral activities [1]. In humans, the type III IFN family consists of four members, IFN- $\lambda 1-4$. Mice have two functional genes encoding IFN- $\lambda$ (IFNL2 and $I F N L 3$ ) and the pseudogene IFNL1. A previous study reported that IFN- $\lambda 1$ exhibited stronger antiviral activity 
than IFN- $\lambda 2$ and IFN- $\lambda 3$ [2]. The receptors of the type III IFN family are composed of two different chains: IFN- $\lambda$ receptor 1 (IFN- $\lambda$ R 1 ), which has high affinity for its ligands, and IL-10 receptor 2 (IL-10R2), which has low affinity [3]. In contrast to ubiquitously expressed type I IFN (IFN- $\alpha / \beta)$ receptors, type II (IFN- $\gamma$ ) receptors, and IL-10R2, IFN- $\lambda$ R 1 is principally expressed on epithelial cells, such as those in the respiratory tract, gastrointestinal tract, and skin [4]. Although type I/II IFNs are used as therapeutics for viral hepatitis (type I) as well as chronic granulomatous disease and osteopetrosis (type II), adverse effects have been reported in clinical settings [5, 6]. Type I and III IFNs both activate the signal transducer and activator of transcription 1 (STAT1)-mediated pathway, resulting in the assembly of IFN-stimulated gene factor 3 , which coordinates the expression of genes containing the IFN-stimulated response element [3]. However, it currently remains unclear whether the functional type III IFN receptor is expressed in the oral mucosa or if its signaling is useful for antiviral functions at the oral barrier.

The oral mucosa is constantly exposed to various pathogens and serves as a barrier against invasion by microorganisms, including fungi, bacteria, and viruses. Therefore, the mucosal epithelium plays a crucial role in initiating and enhancing oral defense mechanisms by releasing various molecules in response to these microorganisms $[7,8]$. The innate immune system constitutes the first line of mucosal defense, and the recognition of microorganisms is performed by pattern recognition receptors (PRRs), which recognize highly conserved molecular patterns, namely pathogen-associated molecular patterns (PAMPs). Viral PAMPs, which are viral DNA and RNA, are recognized by endosomal and cytoplasmic PRRs in various cells, including epithelial cells [9]. A previous study reported that toll-like receptor (TLR) 3 and TLR9, which are PRRs that recognize viral nucleic acids, were expressed in oral epithelia [10]. Moreover, retinoic acid-inducible gene I (RIG-I), which is one of the RIG-I-like receptors of cytosolic RNA sensors, was shown to detect a wide variety of RNA viruses, such as influenza A virus (IAV) [11] and measles virus [12], as well as host-derived RNAs in herpes simplex virus 1 (HSV-1) and IAV-infected cells [13]. A recent study also reported that RIG-I directly counteracted the access of RNA-dependent RNA polymerase to the viral RNA genome, thereby stopping the replication of severe acute respiratory syndrome coronavirus 2 (SARS-CoV-2) [14]. Although functional RIG-I is expressed in immortalized oral keratinocyte and fibroblast cell lines [15], the role of IFN- $\lambda 1$ in RIG-I-mediated antiviral activity in the oral mucosa remains unknown.

To verify our hypothesis that IFN- $\lambda 1$ exerts priming effects for antiviral defense of the oral mucosa without the undesired effects induced by type I and II IFNs, in the present study, we (1) examined type III IFN receptor expression in human gingival keratinocytes, (2) compared the effects of IFNs on the expression of nuclear factor (NF)$\kappa \mathrm{B}$-related genes, such as ILC and IL8, and angiotensinconverting enzyme 2 (ACE2), a SARS-CoV-2-related gene, (3) investigated the effects of IFN- $\lambda 1$ on the production of TLRs and RIG-I, and (4) demonstrated the priming effects of IFN- $\lambda 1$ on RIG-I or TLR3 agonist-induced IL-6, IL-8, and type I IFN (IFN- $\beta$ ) production in human primary gingival keratinocytes (HGK).

\section{MATERIALS AND METHODS}

\section{Reagents}

Reagents were obtained from Sigma-Aldrich (St. Louis, MO, USA) unless otherwise indicated. 3p-hpRNA (tlrl-hprna) and Poly(I:C) (tlrl-pic) were purchased from InvivoGen (San Diego, CA, USA). Recombinant human IFN- $\beta$ (8499-IF-010/CF) and IL-29/IFN $\lambda 1$ (1598-IL) were purchased from R\&D Systems (Minneapolis, MN, USA). Recombinant human IFN- $\gamma$ (570204) and the potent STAT1 inhibitor, S14-95 (ALX-350-299), were purchased from BioLegend (San Diego, CA, USA) and Enzo Life Sciences (Farmingdale, NY, USA), respectively. Lipofectamine RNAiMAX was purchased from Invitrogen (Carlsbad, CA, USA).

\section{Cell culture and stimulation}

HGK (PCS-200-014) and human primary gingival fibroblasts (CRL-2014) were purchased from the American Type Culture Collection and cultured in KGM-Gold ${ }^{\mathrm{TM}}$ BulletKit ${ }^{\mathrm{TM}}$ (Lonza Japan, Tokyo, Japan) and KBM Fibro Assist (KOHJIN BIO, Saitama, Japan), respectively. Human oral keratinocytes (HOK) isolated from the oral mucosa were purchased from ScienCell Research Laboratories (San Diego, CA) and cultured in KGM-Gold ${ }^{\mathrm{TM}}$ BulletKit $^{\mathrm{TM}}$. A Simian virus-40 antigen immortalized human gingival keratinocyte cell line (OBA-9), which was generated by Prof. Shinya Murakami [16], was maintained in Defined Keratinocyte-SFM 
(Gibco, Carlsbad, CA, USA). Normal human lung fibroblasts were provided by the Japanese Collection of Research Bioresources Cell Bank. The HaCaT immortalized human skin keratinocyte cell line was obtained from N. E. Fusenig (German Cancer Research Center, Heidelberg, Germany) and cultured in DMEM supplemented with $10 \%$ FBS. Human primary epidermal keratinocytes (HEK) were purchased from Lifeline Cell Technology (Frederick, MD, USA) and maintained in HuMedia-KG2 (Kurabo Industries, Osaka, Japan). In some experiments, HGK were stimulated with various concentrations of 3p-hpRNA using Lipofectamine RNAiMAX transfection reagent, according to the manufacturer's instructions.

\section{Sample preparation for immunohistochemical (IHC) staining}

Gingival tissues were obtained from patients undergoing routine biopsy at the Division of Oral Surgery (Tokushima University Hospital), after approval by the Ethical Committee of Tokushima University Hospital (No. 3822). Informed consent was obtained from patients. Archived paraffin-embedded tissue specimens were used. Regarding IHC staining, tissue sections were deparaffinized in xylene and rehydrated in descending grades of ethanol. Antigen retrieval was performed using a pressure cooker and citrate phosphate buffer ( $\mathrm{pH}$ 6.0). Endogenous peroxidase activity was blocked with $3 \% \mathrm{H}_{2} \mathrm{O}_{2}$ for 10 min. Sections were then blocked with 5\% normal goat serum and treated with normal rabbit IgG (148-09551; Wako, Osaka, Japan) or a polyclonal anti-IL28RA (IFN- $\lambda$ R1) antibody (ab224395; Abcam, Cambridge, MA, USA) at $4{ }^{\circ} \mathrm{C}$ overnight (final concentration, $1.5 \mu \mathrm{g} / \mathrm{ml}$ ). After the incubation with the secondary antibody, the reaction was detected by diaminobenzidine (Dako, Tokyo, Japan) staining. Sections were then counterstained with hematoxylin, dehydrated in ascending grades of ethanol, and mounted on slides. Images were acquired using a KEYENCE BZ-X800 microscope (Osaka, Japan).

\section{Measurement of IL-6, IL-8, and IFN- $\beta$ production by ELISA}

HGK were seeded on 12 -well plates $\left(5 \times 10^{5}\right.$ cells/ well) and incubated overnight. Treatments are described in the figure legends. The amounts of IL-6, IL-8, and IFN- $\beta$ in media were assessed using the OptEIA Human IL-6 ELISA set (555220; BD Biosciences, San Diego,
CA, USA), OptEIA Human IL-8 ELISA set (555244; BD Biosciences), and Human IFN-beta Quantikine ELISA (DIFNB0; R\&D Systems), respectively.

\section{Western blot analysis}

After the treatment, cells were washed twice with ice-cold PBS and lysed with RIPA buffer supplemented with protease and phosphatase inhibitor cocktail (Thermo Fisher Scientific). Lysates were centrifuged at $12,000 \times g$ at $4{ }^{\circ} \mathrm{C}$ for $10 \mathrm{~min}$, and supernatants were collected. Protein concentrations were measured using the BCA protein assay kit (Thermo Fisher Scientific), and then adjusted and diluted with Laemmli Sample Buffer. After boiling at $95^{\circ} \mathrm{C}$ for $5 \mathrm{~min}$, proteins were separated by sodium dodecyl sulfate-polyacrylamide gel electrophoresis and transferred to polyvinylidene difluoride membranes (Bio-Rad, Hercules, CA, USA). Membranes were incubated with antibodies against GAPDH (5174), IFN regulatory factor 3 (IRF-3, 4302), NF-кB p65 (8242), phospho-IRF-3 (37829), phospho-NF-кB p65 (3033), phospho-STAT1 (7649), RIG-I (3743), STAT1 (9172), TLR3 (6961), and TLR9 (13674), which were purchased from Cell Signaling Technology (Danvers, MA, USA). An ACE2 (AF933) antibody was purchased from R\&D Systems. In some experiments, antibodies were diluted in Can Get Signal (Toyobo, Osaka, Japan). Blots were visualized using Amersham Imager 680 and a densitometric analysis using Amersham Imager 680 Analysis Software (GE Healthcare, Piscataway, NJ, USA) with the chemiluminescence reagent Immunostar (Wako).

\section{Flow cytometric analysis}

Cells were detached with TrypLE Express (Thermo Fisher Scientific), incubated for 10 min with Human TruStain FcX (BioLegend), and then stained with PE mouse $\operatorname{IgG} 2 \mathrm{a}$ (400,213; BioLegend) or a PE antihuman IL-28RA (IFN- $\lambda$ R1) antibody (337,803; BioLegend). Expression was detected using a Canto II flow cytometer and analyzed with FlowJo software (BD Biosciences).

\section{Polymerase chain reaction (PCR) analysis}

Total RNA was extracted using a RNeasy Mini Kit (Qiagen, Valencia, CA, USA) according to the manufacturer's instructions. Total RNA concentrations were measured using a NanoDrop spectrophotometer (Thermo Fisher Scientific), and cDNA was synthesized with PrimeScript RT Master Mix 
(Takara Bio Inc., Shiga, Japan). Regarding reverse transcription (RT)-PCR, cDNA was synthesized from $1 \mu \mathrm{g}$ of total RNA and reacted with the following primers: (IFNLRI) forward, 5'-CGCCTTGGAAGAGTCACTCA-3', and reverse, 5'-GAAGCCTCAGGTCCCAATTC-3'; (IL1OR2) forward, 5'-GGCTGAATTTGCAGATGAGCA-3', and reverse, 5'-GAAGACCGAGGCCATGAGG-3'; $(G A P D H)$ forward, 5'-GCCACATCGCTCAGACAC and reverse, 5'-CTCGCT CCTGGAAGATGG-3'. PCR products were analyzed by agarose gel electrophoresis, and bands were visualized using a Gel Documentation System (AE-6931FXCF; ATTO, Tokyo, Japan). Quantitative real-time PCR was performed on a LightCycler 96 system using FastStart Essential DNA Green Master (Roche Diagnostics GmBH, Germany). The following primers were used for the amplification of specific genes: (ACE2) forward, 5'-CGAAGCCGAAGACCT GTTCTA-3', and reverse, 5'-GGGCAAGTGTGGACTGTT CC-3'; (DDX58) forward, 5'-GATGCCCTAGACCATGCA GG-3', and reverse, 5'-GCCATCATCCCCTTAGTAGAGC; (IFNBI) forward, 5'-ATGACCAACAAGTGTCTCCTCC3', and reverse, 5'-GCTCATGGAAAGAGCTGTAGTG-3'; (IFNL2 and IFNL3) forward, 5'-AGTTCCGGGCCTGTA TCCAG-3', and reverse, 5'-GAGCCGGTACAGCCAATG GT-3'; (IL6) forward, 5'-AAGCCAGAGCTGTGCAGATGA GTA-3', and reverse, 5'-TGTCCTGCAGCCACTGGTTC-3'; (ILS) forward, 5'-ATGACTTCCAAGCTGGCCGTGGC-3', and reverse, 5'-TCTCAGCCCTCTTCAAAAACTTCTC; (TLR3) forward, 5'-GCATTTGTTTTCTCACTCTTT-3', and reverse, 5'-TTAGCCACTGAAAAGAAAAAT. The primers for IFNARI and GAPDH were described above. The relative quantification of gene expression was performed according to the $2(-\Delta \Delta \mathrm{CT})$ method and normalized against GAPDH mRNA.

\section{Statistical analysis}

The significance of differences was evaluated using the Student's unpaired $t$-test or Dunnett's multiple comparison test after an analysis of variance using GraphPad InStat (version 3.10, GraphPad InStat Software Inc.). Values of $p<0.05$ were considered to be significant.

\section{RESULTS}

\section{IFN- $\lambda R 1$ expression in human gingival keratinocytes}

We investigated whether human gingival epithelial cells and fibroblasts in culture expressed the receptors for type III IFN and cell surface IFN- $\lambda$ R1 using PCR and flow cytometry, respectively. Although we confirmed IL1OR2 (a low-affinity receptor for type III IFNs) mRNA expression in all cells tested, IFNLRI (a high-affinity receptor for type III IFNs) mRNA was only expressed in keratinocytes derived from skin or gingiva (Fig. 1A). The results of the quantitative real-time PCR analysis showed that IFNLRI mRNA expression levels were higher in gingival keratinocytes than in skin keratinocytes (Fig. 1B). Moreover, the cell surface expression levels of IFN- $\lambda$ R1 were higher in OBA-9 and HGK than in HEK (Fig. 1C). We then examined the effects of a treatment with IFN- $\lambda 1$ on STAT1 activation. The treatment with IFN$\lambda 1$ dose-dependently induced the phosphorylation of STAT1 in HGK (Fig. 1D) and HOK (Supplementary Fig. 1). We also confirmed IFN- $\lambda \mathrm{R} 1$ expression in the surface human gingival mucosa by the IHC staining of human gingival tissues (Fig. 1E). These results suggest that IFN- $\lambda 1$ signaling may have a functional role in the human oral mucosa.

\section{Comparison of effects of IFNs on IL-6, IL-8, and ACE2 expression in HGK}

In the oral mucosa, epithelial cells play an active role in host defenses against bacteria and viruses by releasing proinflammatory cytokines, such as IL-6 and IL-8 [10]. Therefore, we investigated whether IFNs themselves induce the mRNA expression and production of these proteins using real-time PCR and ELISA, respectively. Although all IFNs tested increased IL6 mRNA expression levels over those in untreated cells, IFN- $\beta$ increased mRNA expression levels significantly more than the two IFNs after a 24-h incubation (Fig. 2A). In the case of $I L 8$, IFN- $\gamma$ significantly increased its mRNA expression levels, and this effect persisted for $48 \mathrm{~h}$ (Fig. 2B). No significant differences were observed in IFNL2 or IFNL3 mRNA levels between the cells examined (data not shown). The corresponding production of the IL-6 (Fig. 2C) and IL-8 (Fig. 2D) proteins was confirmed by ELISA. Recent studies reported that the epithelial cells of skin [17] and the oral mucosa $[18,19]$ expressed ACE2, which is a critical receptor for SARS-CoV-2, and also that type I IFN enhanced the expression of ACE2 in primary human airway epithelial cells [20]. In HGK, we confirmed that IFN$\beta$, but not IFN- $\gamma$ or IFN- $\lambda 1$, significantly increased ACE2 mRNA expression levels (Fig. 2E). The expression of the ACE2 protein was significantly higher in IFN- $\beta$-treated cells than in IFN- $\lambda 1$-treated cells (Fig. 2 F). The truncated form (approximately $75 \mathrm{kDa}$ ) of the ACE2 protein has also been detected in human plasma [21] and COS7 cells [22]. 


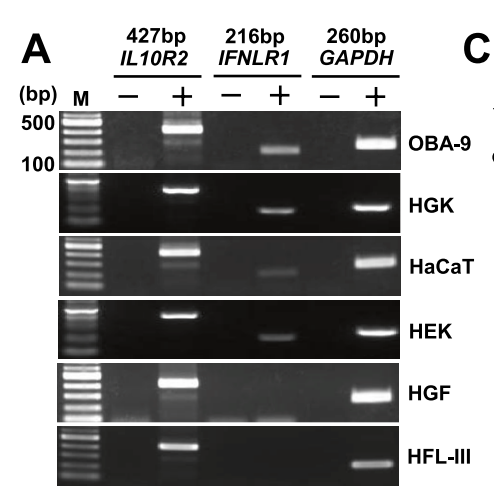

B

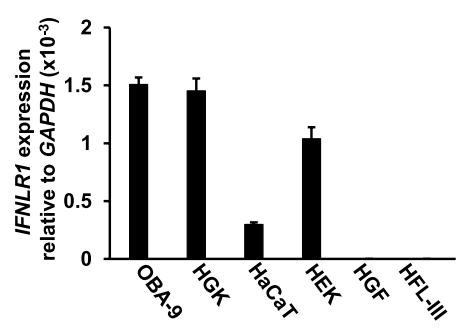

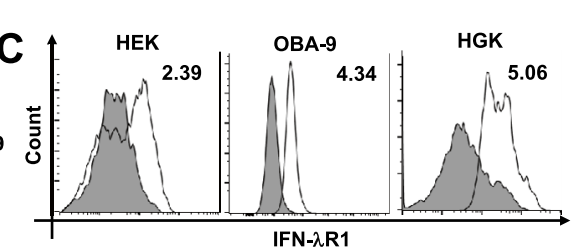
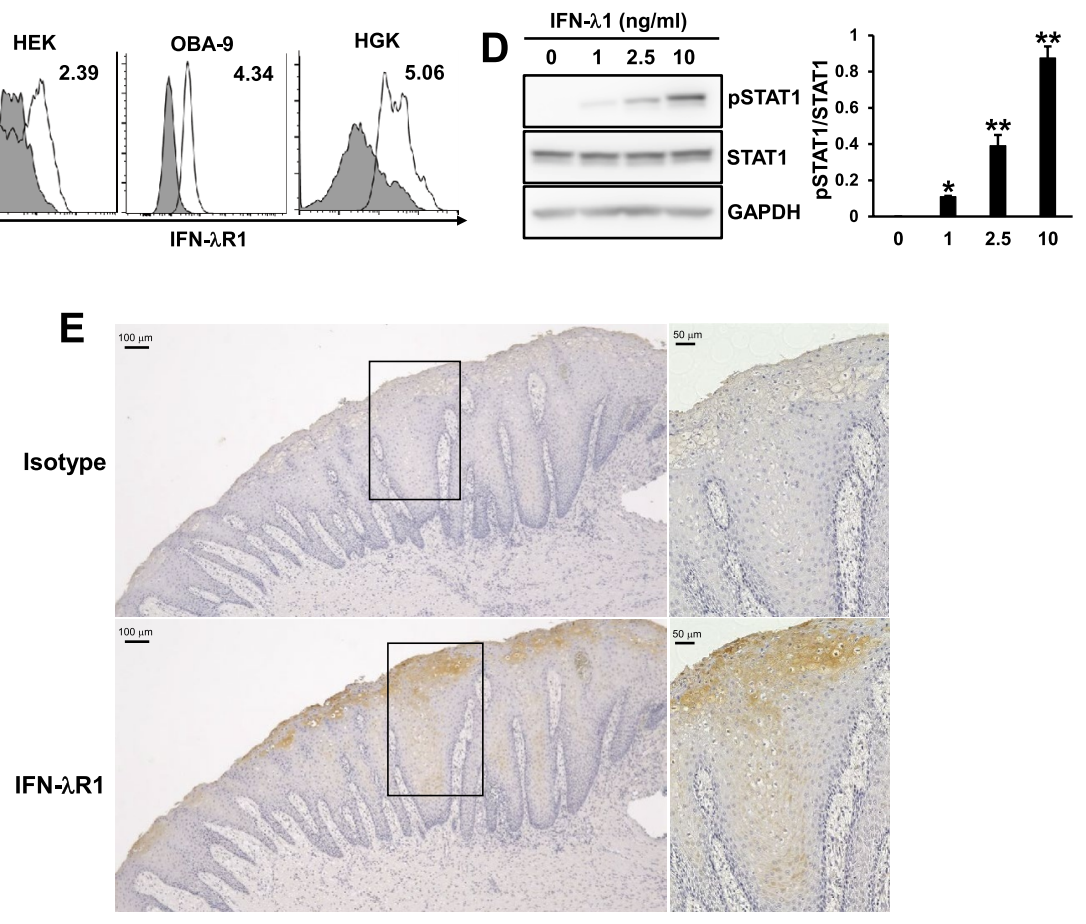

Fig. 1 Type III IFN receptor expression in human gingival keratinocytes. A: Detection of ILIOR2, IFNLR1, and GAPDH mRNA in various keratinocytes and fibroblasts with (+) or without (-) cDNA by RT-PCR. M, marker. B: Quantitative analysis of IFNLR1 mRNA expression by real-time PCR in various keratinocytes and fibroblasts. Data represent the mean \pm standard deviation (SD) of triplicate assays. C: Detection of cell surface IFN- $\lambda$ R 1 by flow cytometry. The black line represents IFN- $\lambda$ R 1 , and the gray area shows the isotype control. A representative histogram from three independent experiments is shown. Values are the mean fluorescence intensity of IFN- $\lambda$ R1 expression and shown as a fold increase in IFN- $\lambda$ R1 expression from that with the control. D: HGK were treated with the indicated concentrations of IFN- $\lambda 1$ for 30 min. Whole-cell lysates prepared from these cells were immunoblotted with anti-phospho-STAT1 (pSTAT1), anti-STAT1, or anti-GAPDH antibodies. A representative blot is shown. The bar graph shows the integrated signal intensities of the pSTAT1/STAT1 ratio. Data represent the mean \pm SD of triplicate assays. $* P<0.05$ and $* * P<0.01$ versus untreated cells ( 0$)$ (Dunnett's multiple comparison test). E: Human gingival sections were stained with an isotype and anti-IFN- $\lambda$ R1 antibody. Sections were counterstained with hematoxylin. Representative images of 3 samples each are shown. The right image is a high-magnification image of the square area. A-D: Data show a representative of at least three independent experiments. OBA-9; an immortalized human gingival keratinocyte cell line. HGK; human primary gingival keratinocytes. HaCaT; an immortalized human skin keratinocyte cell line. HEK; human primary epidermal keratinocytes. HGF; human primary gingival fibroblasts. HFL-III; normal human lung fibroblasts.

These results suggest that IFN- $\lambda 1$ exerted weaker effects on the induction of proinflammatory cytokines and ACE2 than other IFNs.

\section{The IFN- $\lambda 1$ treatment induces the expression of RIG-I and TLR3 via the STAT1-mediated pathway in HGK}

A previous study reported that gingival epithelial cells expressed TLR3 (a receptor for viral double-stranded RNA) and TLR9 (a receptor for the unmethylated CpG DNA of bacterial and viral origins) [10]. Immortalized oral keratinocytes have also been shown to express functional RIG-I [15], which was induced by IFN- $\lambda 1$ signaling in melanoma cells [23]. Therefore, we next investigated whether a treatment with IFN- $\lambda 1$ induced the expression of TLR3, TLR9, and RIG-I in HGK. Although the treatment with IFN- $\lambda 1$ did not affect TLR9 protein expression levels (Supplementary Fig. 2), dose-dependent elevations were noted in TLR3 and RIG-I expression levels, with significant increases being observed with $1 \mathrm{ng} / \mathrm{ml}$ of IFN- $\lambda 1$ (Fig. 3A). Moreover, IFN- $\lambda 1$-induced RIG-I and TLR3 expression levels were dose-dependently decreased by a co-incubation with S14-95, a potent STAT1 inhibitor (Fig. 3B). In comparisons of the effects of IFNs on the expression levels of these proteins, DDX58 (RIG-I) (Fig. 3C) and TLR3 (Fig. 3D) mRNA expression levels induced by IFN- $\lambda 1$ peaked after $24 \mathrm{~h}$, and the strongest 

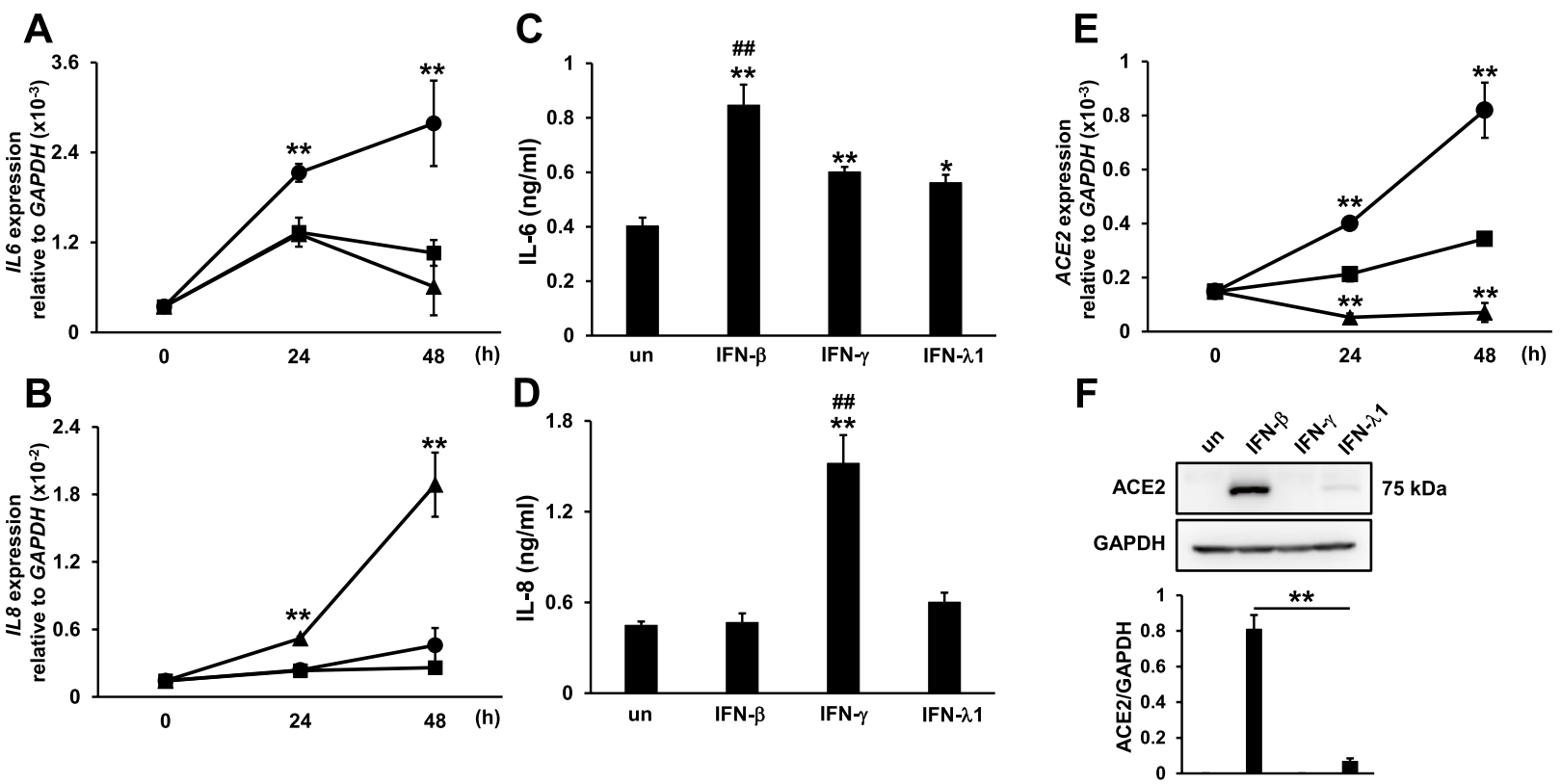

Fig. 2 Effects of IFNs on IL-6, IL-8, and ACE2 expression in HGK. A, B: Cells were treated with IFN- $\beta(\bullet)$, IFN- $\gamma(\boldsymbol{\Delta})$, or IFN- $\lambda 1(\boldsymbol{\square})$ at 10 ng/ $\mathrm{ml}$ each for the indicated times. A: $I L 6$ and $\mathbf{B}: I L 8 \mathrm{mRNA}$ expression levels were quantified using real-time PCR. $* * P<0.01$ versus IFN- $\lambda 1$-treated cells at the same time point (the Student's unpaired $t$-test). C, D: Cells were treated with IFN- $\beta$, IFN- $\gamma$, or IFN- $\lambda 1$ at $10 \mathrm{ng} / \mathrm{ml}$ each for $24 \mathrm{~h}$. The concentrations of C: IL-6 and D: IL-8 in the medium were assessed by ELISA. ${ }^{*} P<0.05$ and ${ }^{*} P<0.01$ versus untreated cells (un) (Dunnett's multiple comparison test). ${ }^{\# \#} P<0.01$ versus IFN- $\lambda 1$-treated cells (the Student's unpaired $t$-test). E: Cells were treated with either IFN- $\beta(\bullet)$, IFN- $\gamma$ $(\boldsymbol{\Delta})$, or IFN- $\lambda 1(\boldsymbol{\square})$ at $10 \mathrm{ng} / \mathrm{ml}$ each for the indicated times. ACE2 mRNA expression levels were quantified using real-time PCR. $* * P<0.01$ versus IFN- $\lambda 1$-treated cells at the same time point (the Student's unpaired $t$-test). F: Whole-cell lysates were prepared from cells treated with IFN- $\beta$, IFN- $\gamma$, or IFN- $\lambda 1$ at $10 \mathrm{ng} / \mathrm{ml}$ each for $48 \mathrm{~h}$. Cell lysates were immunoblotted with anti-ACE2 and anti-GAPDH antibodies. A representative blot is shown. The bar graph shows the integrated signal intensities of the ACE2/GAPDH ratio. ${ }^{*} P<0.01$ (the Student's unpaired $t$-test). A-F: Data represent the mean $\pm \mathrm{SD}$ of triplicate assays and show a representative of at least three independent experiments.

inducer of these genes was IFN- $\beta$. We also confirmed that the order of potential to induce these molecules at the protein level was IFN- $\beta>$ IFN- $\lambda 1>$ IFN- $\gamma$ by Western blotting (Fig. 3E). These results suggest that IFN- $\lambda 1$ exerted priming effects on RIG-I and TLR3 agonist-induced responses by up-regulating the expression of these receptors via the STAT1-mediated pathway.

\section{Priming effects of IFN- $\lambda 1$ on 3p-hpRNA-induced IFN- $\beta$ production in HGK}

RIG-I signaling bifurcates into two molecular cascades: one involves TANK-binding kinase- 1 and IкB kinase epsilon (IKKe), which directly phosphorylate IRF 3 and 7, to up-regulate the expression of type I IFNs, while the other engages the IKK $\alpha / \beta / \gamma$ complex and induces the NF- $\kappa B$-dependent up-regulation of proinflammatory gene expression [24]. Using 3p-hpRNA, a 5' triphosphate hairpin RNA and specific agonist of RIG-I, we investigated whether the increase induced in RIG-I expression levels by IFN- $\lambda 1$ enhanced 3p-hpRNA-induced IFN- $\beta$ production in HGK. A stimulation with $3 p-h p R N A$ dose-dependently induced IRF3 phosphorylation (Fig. 4A), and dose- and timedependently induced IFNBI mRNA expression (Fig. 4B) in HGK. Moreover, the level of IRF3 phosphorylation induced by the 3 p-hpRNA stimulation pretreated with IFN- $\lambda 1$ was fourfold greater than that by the $3 \mathrm{p}$-hpRNA stimulation alone (Fig. 4C). The priming effects of IFN- $\lambda 1$ were also confirmed by 3p-hpRNA-induced IFNBI mRNA expression (Fig. 4D), and the secretion level of IFN- $\beta$ induced by the 3p-hpRNA stimulation following a pretreatment with IFN- $\lambda 1$ was eightfold greater than that by the $3 p-h p R N A$ stimulation alone (Fig. 4E). These results suggest that IFN- $\lambda 1$ increased $3 p-h p R N A-i n d u c e d$ IFN- $\beta$ production by enhancing the phosphorylation of IRF3. 


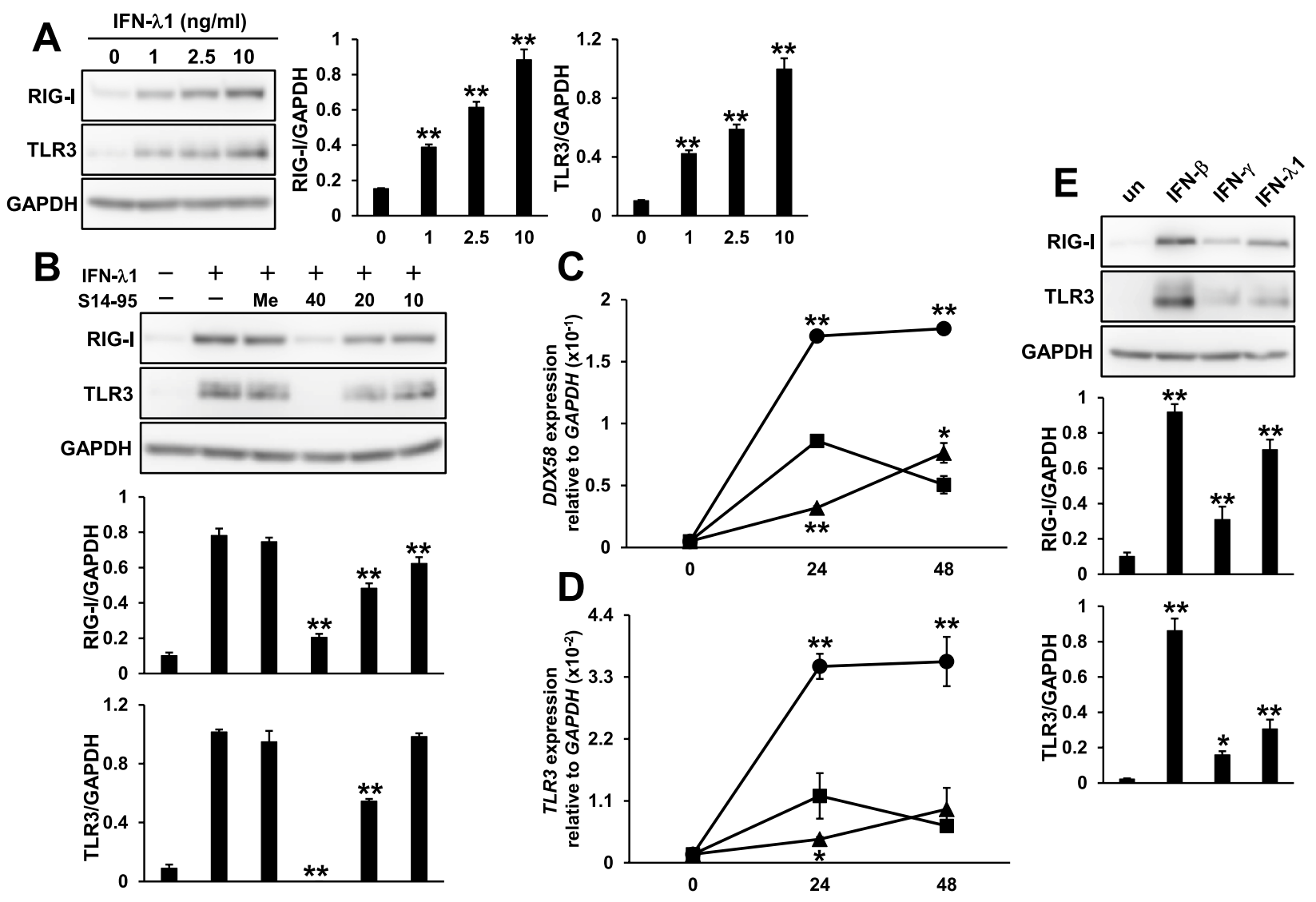

Fig. 3 IFN- $\lambda 1$ induces RIG-I and TLR3 expression via the STAT1-mediated pathway in HGK. A: Whole-cell lysates were prepared from cells treated with the indicated concentrations of IFN- $\lambda 1$ (ng/ml) for $24 \mathrm{~h}$. Cell lysates were immunoblotted with anti-RIG-I, anti-TLR3, and anti-GAPDH antibodies. A representative blot is shown. The bar graph shows the integrated signal intensities of the RIG-I/GAPDH or TLR3/GAPDH ratio. $* * P<0.01$ versus untreated cells $(0)$ (Dunnett's multiple comparison test). B: Whole-cell lysates were prepared from cells treated with $10 \mathrm{ng} / \mathrm{ml}$ IFN- $\lambda 1$ in combination with S14-95 $(\mu \mathrm{M})$, a potent STAT1 inhibitor, at the indicated concentrations or methanol (Me), its solvent, for $24 \mathrm{~h}$. Cell lysates were immunoblotted with anti-RIG-I, anti-TLR3, and anti-GAPDH antibodies. A representative blot is shown. The bar graph shows the integrated signal intensities of the RIG-I/GAPDH or TLR3/GAPDH ratio. ${ }^{* *} P<0.01$ versus IFN- $\lambda 1$-treated cells. (Dunnett's multiple comparison test). C, D: Cells were treated with IFN- $\beta(\bullet), \operatorname{IFN}-\gamma(\boldsymbol{\Delta})$, or IFN- $\lambda 1(\boldsymbol{\square})$ at $10 \mathrm{ng} / \mathrm{ml}$ each for the indicated times. C: DDX58 (RIG-I) and D: TLR3 mRNA expression levels were quantified using real-time PCR. $* P<0.05$ and $* * P<0.01$ versus IFN- $\lambda 1$-treated cells at the same time point (the Student's unpaired $t$-test). E: Whole-cell lysates were prepared from cells treated with IFN- $\beta$, IFN- $\gamma$, or IFN- $\lambda 1$ at $10 \mathrm{ng} / \mathrm{ml}$ each for $24 \mathrm{~h}$. Cell lysates were immunoblotted with anti-RIG-I, anti-TLR3, and anti-GAPDH antibodies. A representative blot is shown. The bar graph shows the integrated signal intensities of the RIG-I/GAPDH or TLR3/GAPDH ratio. $* P<0.05$ and $* * P<0.01$ versus untreated cells (un) (Dunnett's multiple comparison test). A-E: Data represent the mean $\pm \mathrm{SD}$ of triplicate assays and show a representative of at least three independent experiments.

\section{Priming effects of IFN- $\lambda 1$ on 3p-hpRNA-induced IL-6 and IL-8 production in HGK}

Previous studies suggested a role for RIG-I in viral defenses because of its recognition of virus-derived RNA, particularly in non-immune cells [25]. In the oral mucosa and periodontal lesions, fibroblasts and epithelial cells play an active role in host defenses, releasing a number of proinflammatory mediators, such as IL-6 and IL-8, induced by the activation of NF-kB [26, 27]. Therefore, we examined the priming effects of IFN- $\lambda 1$ on $3 p-R N A$-induced IL- 6 and IL-8 production in HGK. The 3p-hpRNA stimulation dosedependently increased NF- $\kappa$ B phosphorylation (Fig. 5A) as well as IL6 and IL8 mRNA expression levels (Fig. 5B). Moreover, the IFN- $\lambda 1$ pretreatment significantly increased 3p-hpRNA-induced NF-кB phosphorylation (Fig. 5C), IL6 and $I L 8 \mathrm{mRNA}$ expression (Fig. 5D), and the production of 

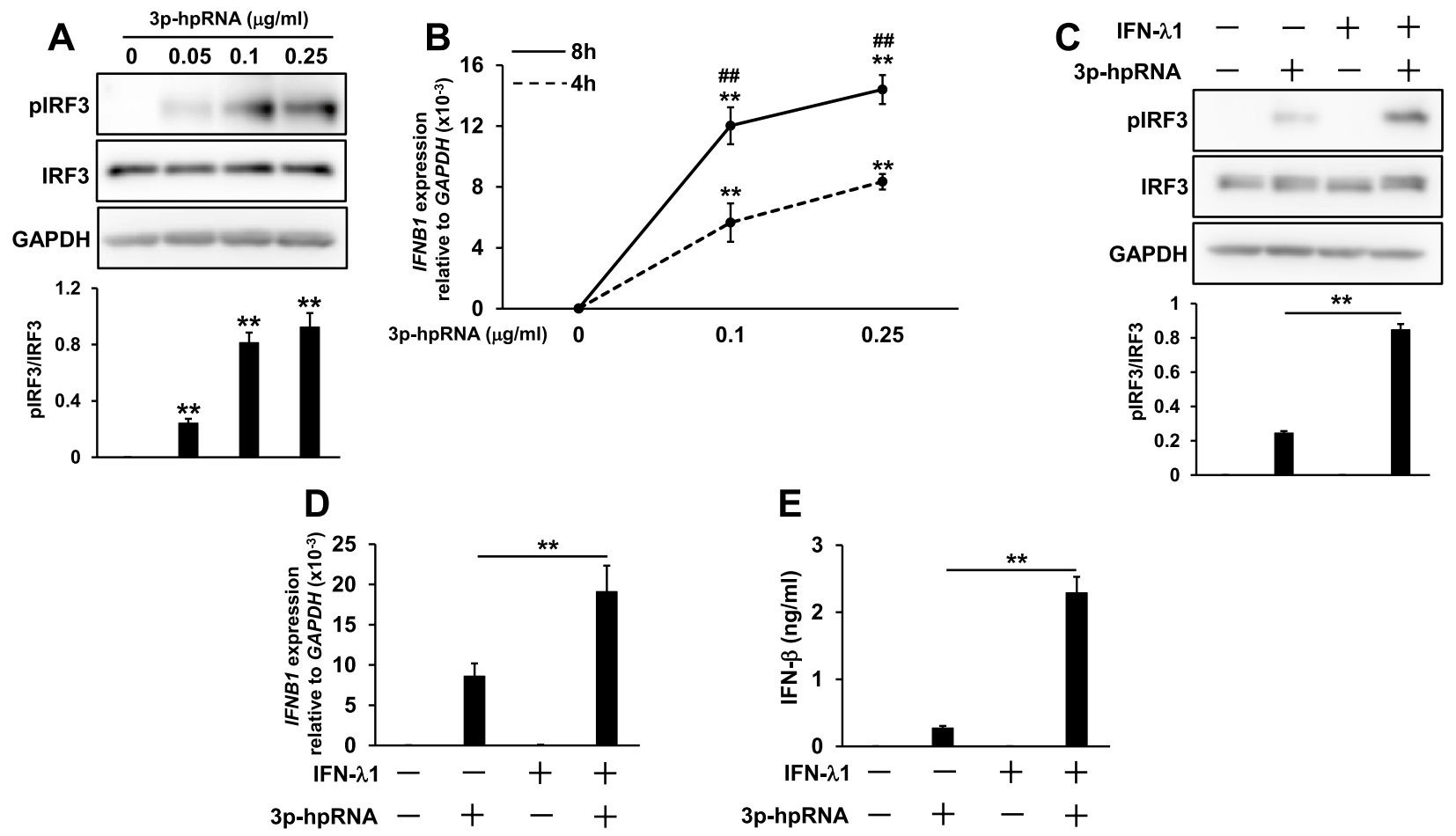

Fig. 4 Priming effects of the IFN- $\lambda 1$ treatment on 3p-hpRNA-induced IFN- $\beta$ production in HGK. A: Whole-cell lysates were prepared from cells treated with the indicated concentrations of 3p-hpRNA $(\mu \mathrm{g} / \mathrm{ml})$ for $3 \mathrm{~h}$. Cell lysates were immunoblotted with anti-phospho-IRF3 (pIRF3), antiIRF3, and anti-GAPDH antibodies. A representative blot is shown. The bar graph shows the integrated signal intensities of the pIRF3/IRF3 ratio. $* * P<0.01$ versus untreated cells ( 0$)$ (Dunnett's multiple comparison test). B: Cells were treated with the indicated concentrations of 3p-hpRNA ( $\mu \mathrm{g} /$ $\mathrm{ml}$ ) for $4 \mathrm{~h}$ (dashed line) or $8 \mathrm{~h}$ (solid line). IFNB1 mRNA expression levels were quantified using real-time PCR. $* * P<0.01$ versus untreated cells (0) at the same time point (Dunnett's multiple comparison test). ${ }^{\#} P<0.01$ versus the 4-h treated group at the same concentration point (the Stu-

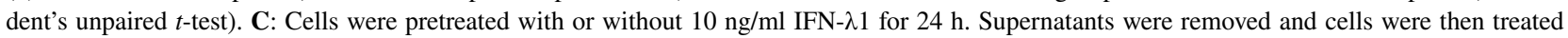
with or without $0.1 \mu \mathrm{g} / \mathrm{ml} 3 \mathrm{p}-\mathrm{hpRNA}$ for $3 \mathrm{~h}$. Whole-cell lysates were collected and immunoblotted with anti-pIRF3, anti-IRF3, and anti-GAPDH antibodies. A representative blot is shown. The bar graph shows the integrated signal intensities of the pIRF3/IRF3 ratio. $* * P<0.01$ (the Student's

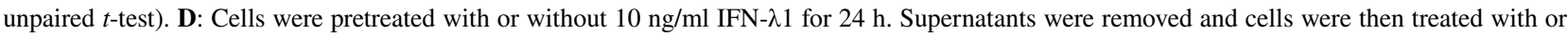
without $0.1 \mu \mathrm{g} / \mathrm{ml} 3 \mathrm{p}$-hpRNA for $4 \mathrm{~h}$. The IFNB1 mRNA expression level was quantified using real-time PCR. ** $P<0.01$ (the Student's unpaired $t$-test). E: Cells were pretreated with or without $10 \mathrm{ng} / \mathrm{ml} \mathrm{IFN}-\lambda 1$ for $24 \mathrm{~h}$. Supernatants were removed and cells were then treated with or without $0.1 \mu \mathrm{g} / \mathrm{ml} \mathrm{3p-hpRNA}$ for $4 \mathrm{~h}$. The concentration of IFN- $\beta$ in the medium was assessed by ELISA. $* * P<0.01$ (the Student's unpaired $t$-test). A-E: Data represent the mean \pm SD of triplicate assays and show a representative of at least three independent experiments.

these cytokines (Fig. 5E). These results suggest that IFN- $\lambda 1$ increased 3p-hpRNA-induced IL-6 and IL-8 production by enhancing NF- $\mathrm{KB}$ phosphorylation.

\section{The IFN- $\lambda 1$ pretreatment increases TLR3 agonist-induced IFN- $\beta$, IL-6, and IL-8 production in HGK}

TLR3 is one of the important PRRs against viral infections in the oral cavity because HSV-1, which causes oral herpes, produces dsRNA, a ligand of TLR3 [28]. Its signaling activates the NF- $\mathrm{KB}$ and IRF3 signaling pathways to facilitate the release of proteins regulated by these molecules for defense against viruses [29]. Previous studies reported that a stimulation with the TLR3 ligand, Poly(I:C) induced the expression of NF-KB [30] and IRF3 [31] target genes in gingival keratinocytes; therefore, we examined the effects of the IFN- $\lambda 1$ treatment on the Poly(I:C)-induced activation of NF- $\mathrm{KB}$ and IRF3 signaling. IRF3 (Fig. 6A) and NF- $\mathrm{KB}$ (Fig. 6B) phosphorylation levels induced by the Poly(I:C) stimulation after the pretreatment with IFN- $\lambda 1$ were 13 - and 2.5 -fold greater, respectively, than those by the Poly(I:C) stimulation alone. We also confirmed that the IFN- $\lambda 1$ pretreatment significantly increased Poly(I:C)-induced IFNBI, IL6, and IL8 mRNA expression levels (Fig. 6C) and 

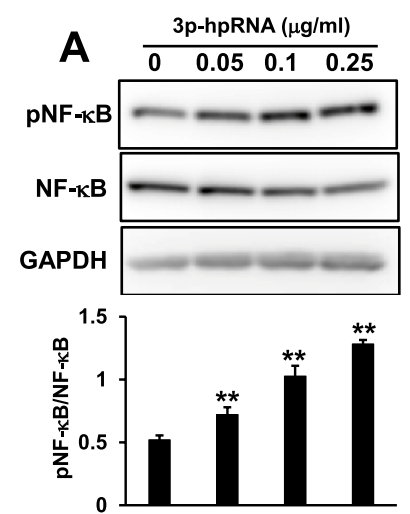

D

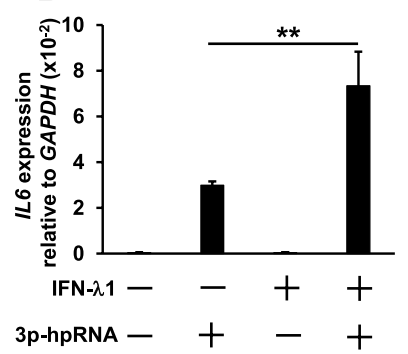

B
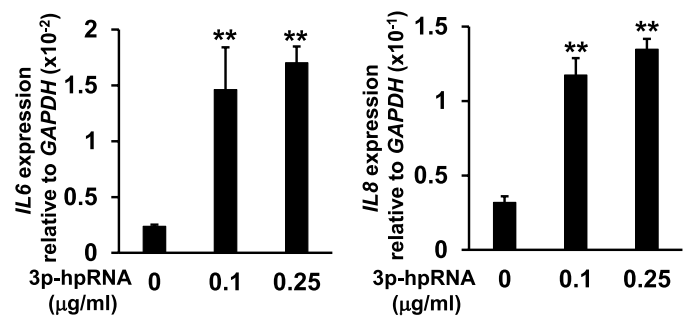

E

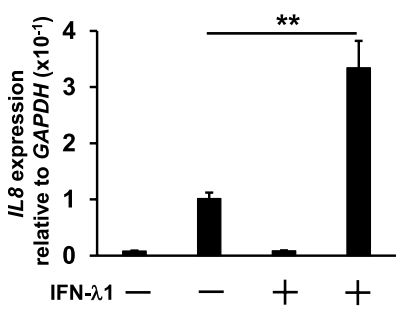

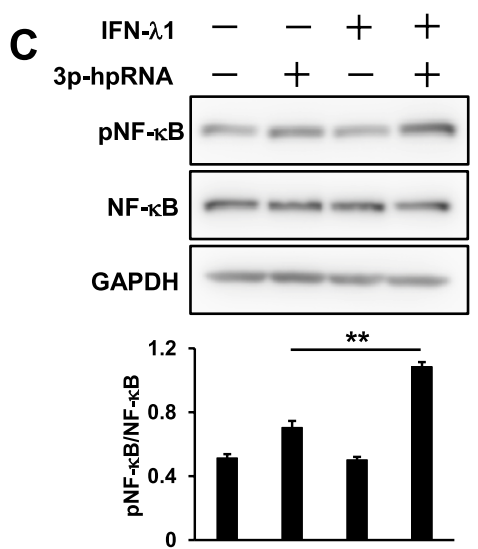

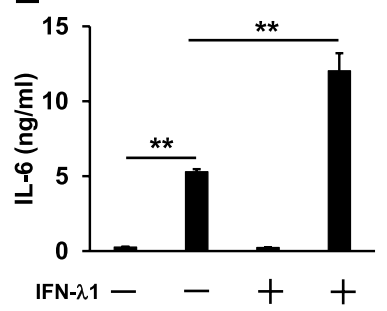

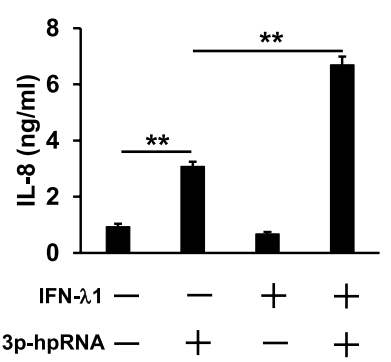

Fig. 5 IFN- $\lambda 1$ pretreatment augments 3p-hpRNA-induced IL-6 and IL-8 production in HGK. A: Whole-cell lysates were prepared from cells

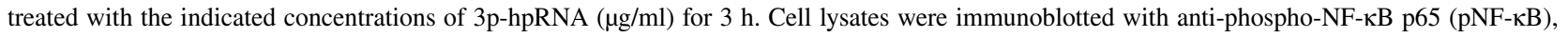
anti-NF- $\kappa \mathrm{B}$ p65 (NF- $\mathrm{kB})$, and anti-GAPDH antibodies. A representative blot is shown. The bar graph shows the integrated signal intensities of the pNF- $\mathrm{kB} / \mathrm{NF}-\mathrm{\kappa B}$ ratio. ${ }^{*} P<0.01$ versus untreated cells $(0)$ (Dunnett's multiple comparison test). B: Cells were treated with the indicated concentrations of $3 \mathrm{p}-\mathrm{hpRNA}(\mu \mathrm{g} / \mathrm{ml})$ for $12 \mathrm{~h}$. IL6 and $I L 8 \mathrm{mRNA}$ expression levels were quantified using real-time PCR. $* * P<0.01$ versus untreated cells (0) (Dunnett's multiple comparison test). C: Cells were pretreated with or without $10 \mathrm{ng} / \mathrm{ml} \mathrm{IFN}-\lambda 1$ for $24 \mathrm{~h}$. Supernatants were removed and cells were then treated with or without $0.1 \mu \mathrm{g} / \mathrm{ml} 3 \mathrm{p}$-hpRNA for $3 \mathrm{~h}$. Whole-cell lysates were collected and immunoblotted with anti-pNF- $\mathrm{kB}$, anti$\mathrm{NF}-\mathrm{\kappa B}$, and anti-GAPDH antibodies. A representative blot is shown. The bar graph shows the integrated signal intensities of the pNF- $\mathrm{kB} / \mathrm{NF}-\mathrm{\kappa B}$ ratio. ${ }^{*} P<0.01$ (the Student's unpaired $t$-test). D: Cells were pretreated with or without $10 \mathrm{ng} / \mathrm{ml} \mathrm{IFN}-\lambda 1$ for 24 h. Supernatants were removed and cells were then treated with or without $0.1 \mu \mathrm{g} / \mathrm{ml} 3 \mathrm{p}$-hpRNA for $4 \mathrm{~h}$. IL6 and IL8 mRNA expression levels were quantified using real-time PCR. ${ }^{* *} P<0.01$ (the Student's unpaired $t$-test). E: Cells were pretreated with or without $10 \mathrm{ng} / \mathrm{ml}$ IFN- $\lambda 1$ for $24 \mathrm{~h}$. Supernatants were removed and HGK were then treated with or without $0.1 \mu \mathrm{g} / \mathrm{ml} 3 \mathrm{p}$-hpRNA for $4 \mathrm{~h}$. The concentrations of IL- 6 and IL- 8 in the medium were assessed by ELISA. $* * P<0.01$ (the Student's unpaired $t$-test). A-E: Data represent the mean \pm SD of triplicate assays and show a representative of at least three independent experiments.

promoted the production of these proteins (Fig. 6D) using real-time PCR and ELISA, respectively. Based on the results shown in Figs. 4 and 5, IFN- $\lambda 1$ has the potential to enhance antiviral activity against viruses, which have a ligand for either RIG-I or TLR3, in the oral mucosa.

\section{DISCUSSION}

Accumulating evidence has revealed that IFN- $\lambda 1$ [32] and RIG-I [14] are beneficial for the prevention and treatment of coronavirus disease 2019 (COVID-19) caused by SARS-CoV-2, and also that the oral cavity is an important site for SARS-CoV-2 infection because the oral epithelium expresses ACE2 [18, 19]. The present results demonstrated that IFN- $\lambda$ R 1 was expressed in HGK and the human gingival epithelium (Fig. 1). We also showed that the majority of HGK were positive for IFN- $\lambda$ R 1 , whereas HEK consisted of two populations for the expression of IFN- $\lambda$ R1 (Fig. 1C). This may be attributed to the oral epithelium being more proliferative and thicker than the skin epithelium in addition to differences in the epithelial localization of differentiation markers, such as keratins, loricrin, and involucrin [33]. The expression of IFN- $\lambda \mathrm{R} 1$ has also been reported in a human 


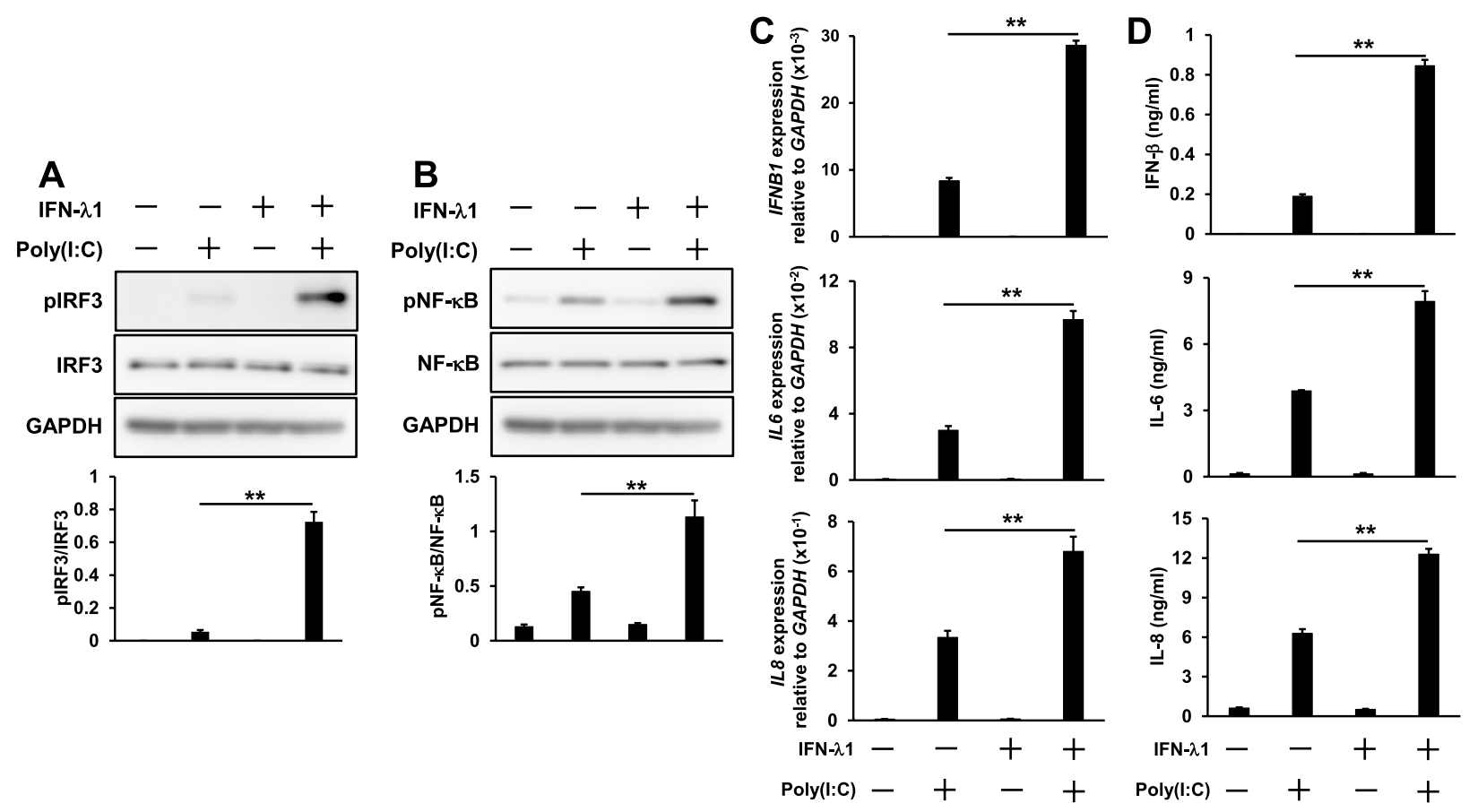

Fig. 6 Priming effects of IFN- $\lambda 1$ on Poly(I:C)-induced IL-6, IL-8, and IFN- $\beta$ expression in HGK. A, B: Cells were pretreated with or without $10 \mathrm{ng} / \mathrm{ml} \mathrm{IFN}-\lambda 1$ for $24 \mathrm{~h}$. Supernatants were removed and cells were then treated with or without $1 \mu \mathrm{g} / \mathrm{ml}$ Poly(I:C) for $1 \mathrm{~h}$. Whole-cell lysates were

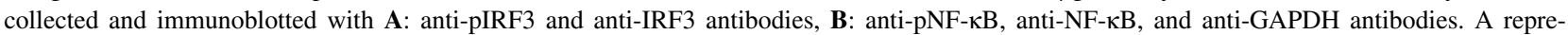
sentative blot is shown. The bar graph shows the integrated signal intensities of the $\mathbf{A}$ : pIRF3/IRF3 ratio and $\mathbf{B}$ : pNF- $\mathrm{kB} / \mathrm{NF}-\mathrm{\kappa B}$ ratio, respectively.

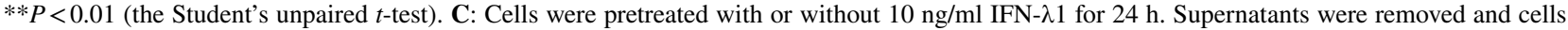
were then treated with or without $1 \mu \mathrm{g} / \mathrm{ml}$ Poly(I:C) for $4 \mathrm{~h}$. IFNB1, IL6, and IL8 mRNA expression levels were quantified using real-time PCR. $* * P<0.01$ (the Student's unpaired $t$-test). D: Cells were pretreated with or without $10 \mathrm{ng} / \mathrm{ml} \mathrm{IFN}-\lambda 1 \mathrm{for} 24 \mathrm{~h}$. Supernatants were removed and cells were then treated with or without $1 \mu \mathrm{g} / \mathrm{ml}$ Poly(I:C) for $4 \mathrm{~h}$. The concentrations of IFN- $\beta$, IL-6, and IL-8 in the medium were assessed by ELISA. $* * P<0.01$ (the Student's unpaired $t$-test). A-D: Data represent the mean \pm SD of triplicate assays and show a representative of at least three independent experiments.

oral epithelial cell line, and IFN- $\lambda 1$ enhanced the production of tumor necrosis factor- $\alpha$-induced CXCL10 (a chemokine that plays a crucial role in Th1 cell accumulation) [34]. Furthermore, IFN- $\lambda 1$ was shown to protect epithelial barrier integrity during bacterial infections [35]. Although we demonstrated that IFN- $\lambda 1$ slightly induced the expression of truncated ACE2 in HGK (Fig. 2F), a recent study reported that the truncated form did not bind to the SARS-CoV-2 spike protein and, thus, was unlikely to increase the cellular entry of SARS-CoV-2 or promote infection [36]. Based on the present results, IFN- $\lambda 1$ may be involved in antiviral immunity and also exhibits activity that is beneficial to the host during infectious encounters at the oral mucosa.

TLR3 is a sensor for viral double-stranded RNA and triggers antiviral immune responses during viral infections [37, 38]. The activation of TLR3 is required for inflammation after injury, and keratinocytes need TLR3 to respond to RNA from damaged cells with the release of inflammatory cytokines [39]. Responses to UV radiationdamaged self-RNAs and UV radiation-damaged keratinocytes [40] as well as self-RNAs, including the necrotic cell supernatant of gingival cells [30], were previously shown to be dependent on TLR3. Therefore, TLR3 may recognize not only viral RNA, but also self-RNAs released from damaged keratinocytes at the oral mucosa. We demonstrated that IFN- $\lambda 1$ induced the expression of TLR3 via the STAT1-mediated pathway (Fig. 3), and enhanced TLR3-mediated IFN- $\beta$, IL-6, and IL-8 production in HGK using Poly(I:C) (Fig. 6). However, the recognition of Poly(I:C) by melanoma differentiation-associated gene 5 and RIG-I has been reported [41]. Based on recent findings showing that TLR3 is also involved in the recognition of SARS-CoV-2 [42], the up-regulated expression of 
RIG-I and TLR3 by IFN- $\lambda 1$ may exert synergistic effects that protect against SARS-CoV-2 infection at the oral mucosa.

PRRs discriminate between 'self' and 'non-self', with non-self-molecules that are potentially harmful being recognized and triggering host defenses, while self-molecules induce self-tolerance. RIG-I detects viral RNA derived from IAV [11], measles virus [12], and host-derived RNAs derived from HSV-1- and IAVinfected cells [13]. Infections by these viruses have been implicated in the onset of disease in the oral mucosa, perioral region, and upper respiratory tract. Moreover, preclinical studies reported that a RIG-I agonist inhibited tumor growth through similar mechanisms to those triggered for the elimination of virally infected cells [43]. These findings indicate that RIG-I is a promising target not only for antiviral activity, but also cancer immunotherapy in the oral mucosa.

The priming effects of IFN- $\lambda 1$ on $3 p-h p R N A-$ and Poly(I:C)-induced IL- 6 , IL- 8 , and IFN- $\beta$ production were confirmed at a dose of $10 \mathrm{ng} / \mathrm{ml}$ (Fig. 4-6), and the concentration of the IFN- $\lambda 1$ treatment did not induce the production of IL- 6 (compared with IFN- $\beta$ ) or IL- 8 (compared with IFN- $\gamma$ ) (Fig. 2). A high dose of IFN- $\lambda 1$ of more than $10 \mathrm{ng} / \mathrm{ml}$ was previously shown to induce the production of chemokines, such as CXCL10, in an oral epithelial cell line [34] and HEK [44] as well as IL-6 and IL-8 production in human peripheral blood mononuclear cells [45]. Based on differences in the expression patterns of IFN- $\lambda$ R 1 and type I/II IFN receptors, IFN- $\lambda 1$, when administered at an appropriate concentration, may be more beneficial than other IFNs for activating barrier functions within the oral mucosa.

One limitation of the present study is that we did not provide evidence for the priming effects of IFN- $\lambda 1$ against antiviral activity using live viruses, such as HSV1 , IAV, and SARS-CoV-2. However, previous studies reported that IFN- $\gamma$ [46] and IFN- $\lambda 1$ [47] up-regulated the expression of TLR3 and enhanced antiviral signaling against HSV-1 infection in HEK, and also that RIG-I and TLR3 both required the induction of IFNs by IAV infection [48]. In future studies, we will examine the enhancing effects of IFN- $\lambda 1$ on antiviral activity against live viral infections in HGK and an in vivo model.

In conclusion, the present results demonstrated that functional IFN- $\lambda \mathrm{R} 1$ was expressed, a treatment with IFN- $\lambda 1$ induced the expression of RIG-I and TLR3, and the IFN- $\lambda 1$ treatment also increased RIG-I and TLR3 agonist-induced IL- 6 , IL- 8 , and IFN- $\beta$ production in
HGK. The present study will promote further research that focuses on IFN- $\lambda 1$ therapy as a valuable strategy to activate barrier functions in the oral mucosa.

\section{SUPPLEMENTARY INFORMATION}

The online version contains supplementary material available at https://doi.org/10.1007/s10753-022-01624-1.

\section{ACKNOWLEDGEMENTS}

We thank Resmi Raju for technical assistance.

\section{AUTHOR CONTRIBUTIONS}

Y. Shikama contributed to study conception, design, data acquisition, analysis, and interpretation, and drafted and critically revised the manuscript; M. Kurosawa contributed to data acquisition and analysis, and critically revised the manuscript; M. Furukawa, Y. Kudo, N. Ishimaru, and K. Matsushita contributed to data interpretation and critically revised the manuscript. All authors gave their final approval and agree to be accountable for all aspects of the work.

\section{FUNDING}

This work was supported by the Research Funding for Longevity Sciences from the National Center for Geriatrics and Gerontology (grant \#29-25 to K. Matsushita) and JSPS KAKENHI Grant Number 18K09548.

\section{AVAILABILITY OF DATA AND MATERIALS}

Data that support the results of the present study are available from the corresponding author upon reasonable request.

\section{DECLARATIONS}

Ethics approval and consent to participate Gingival tissues were obtained from patients undergoing routine biopsy at the Division of Oral Surgery (Tokushima University Hospital), after approval by the Ethical Committee of Tokushima University Hospital (No. 3822). Informed consent was obtained from patients. The present study adheres to the tenets of the Declaration of Helsinki.

Consent for publication All the authors consent to publication.

Competing interests The authors declare that there are no conflicts of interest. 


\section{REFERENCES}

1. Kotenko, S.V., G. Gallagher, V.V. Baurin, A. Lewis-Antes, M. Shen, N.K. Shah, J.A. Langer, F. Sheikh, H. Dickensheets, and R.P. Donnelly. 2003. IFN-lambdas mediate antiviral protection through a distinct class II cytokine receptor complex. Nature Immunology 4: 69-77. https://doi.org/10.1038/ni875.

2. Friborg, J., S. Levine, C. Chen, A.K. Sheaffer, S. Chaniewski, S. Voss, J.A. Lemm, and F. McPhee. 2013. Combinations of lambda interferon with direct-acting antiviral agents are highly efficient in suppressing hepatitis $\mathrm{C}$ virus replication. Antimicrobial Agents and Chemotherapy 57: 1312-1322. https://doi.org/10.1128/aac. 02239-12.

3. Wack, A., E. Terczynska-Dyla, and R. Hartmann. 2015. Guarding the frontiers: The biology of type III interferons. Nature Immunology 16: 802-809. https://doi.org/10.1038/ni.3212.

4. Lazear, H.M., T.J. Nice, and M.S. Diamond. 2015. Interferonlambda: Immune Functions at Barrier Surfaces and Beyond. Immunity 43: 15-28. https://doi.org/10.1016/j.immuni.2015.07.001.

5. Castro, L.S., G.S. Lobo, P. Pereira, M.G. Freire, M.C. Neves, and A.Q. Pedro. 2021. Interferon-Based Biopharmaceuticals: Overview on the Production, Purification, and Formulation Vaccines (Basel) 9 https://doi.org/10.3390/vaccines 9040328 .

6. Tovey, M.G., and C. Lallemand. 2010. Safety, Tolerability, and Immunogenicity of Interferons. Pharmaceuticals (Basel) 3: 11621186. https://doi.org/10.3390/ph3041162.

7. Moutsopoulos, N.M., and J.E. Konkel. 2018. Tissue-Specific Immunity at the Oral Mucosal Barrier. Trends in Immunology 39: 276-287. https://doi.org/10.1016/j.it.2017.08.005.

8. Slots, J., and H. Slots. 2019. Periodontal herpesvirus morbidity and treatment. Periodontol 2000 (79): 210-220. https://doi.org/ 10.1111/prd.12241.

9. Gurtler, C., and A.G. Bowie. 2013. Innate immune detection of microbial nucleic acids. Trends in Microbiology 21: 413-420. https://doi.org/10.1016/j.tim.2013.04.004.

10. Groeger, S., and J. Meyle. 2019. Oral Mucosal Epithelial Cells. Front Immunol 10: 208. https://doi.org/10.3389/fimmu.2019. 00208.

11. Jorgensen, S.E., M. Christiansen, L.B. Ryo, H.H. Gad, J. Gjedsted, P. Staeheli, J.G. Mikkelsen, M. Storgaard, R. Hartmann, and T.H. Mogensen. 2018. Defective RNA sensing by RIG-I in severe influenza virus infection. Clinical and Experimental Immunology 192: 366-376. https://doi.org/10.1111/cei.13120.

12. Runge, S., K.M. Sparrer, C. Lassig, K. Hembach, A. Baum, A. Garcia-Sastre, J. Soding, K.K. Conzelmann, and K.P. Hopfner. 2014. In vivo ligands of MDA5 and RIG-I in measles virusinfected cells. PLoS Pathogens 10:e1004081https://doi.org/10. 1371/journal.ppat.1004081.

13. Chiang, J.J., K.M.J. Sparrer, M. van Gent, C. Lassig, T. Huang, N. Osterrieder, K.P. Hopfner, and M.U. Gack. 2018. Viral unmasking of cellular 5S rRNA pseudogene transcripts induces RIG-Imediated immunity. Nature Immunology 19: 53-62. https://doi. org/10.1038/s41590-017-0005-y.

14. Yamada, T., S. Sato, Y. Sotoyama, Y. Orba, H. Sawa, H. Yamauchi, M. Sasaki, and A. Takaoka. 2021. RIG-I triggers a signaling-abortive anti-SARS-CoV-2 defense in human lung cells. Nature Immunology 22: 820-828. https://doi.org/10.1038/s41590-021-00942-0.

15. Ohta, K., A. Fukui, H. Shigeishi, Y. Ishida, H. Nishi, K. Tobiume, M. Takechi, and N. Kamata. 2014. Expression and function of RIG-I in oral keratinocytes and fibroblasts. Cellular Physiology and Biochemistry 34: 1556-1565. https://doi.org/10.1159/000366359.

16. Kusumoto, Y., H. Hirano, K. Saitoh, S. Yamada, M. Takedachi, T. Nozaki, Y. Ozawa, Y. Nakahira, T. Saho, H. Ogo, Y. Shimabukuro, H. Okada, and S. Murakami. 2004. Human gingival epithelial cells produce chemotactic factors interleukin- 8 and monocyte chemoattractant protein-1 after stimulation with Porphyromonas gingivalis via toll-like receptor 2. Journal of Periodontology 75: 370-379. https://doi.org/10.1902/jop.2004.75.3.370.

17. Xue, X., Z. Mi, Z. Wang, Z. Pang, H. Liu, and F. Zhang. 2020. High Expression of ACE2 on Keratinocytes Reveals Skin as a Potential Target for SARS-CoV-2. The Journal of Investigative Dermatology. https://doi.org/10.1016/j.jid.2020.05.087.

18. Sawa, Y., S. Ibaragi, T. Okui, J. Yamashita, T. Ikebe, and H. Harada. 2021. Expression of SARS-CoV-2 entry factors in human oral tissue. Journal of Anatomy 238: 1341-1354. https:// doi.org/10.1111/joa.13391.

19. Huang, N., P. Pérez, T. Kato, Y. Mikami, K. Okuda, R.C. Gilmore, C.D. Conde, B. Gasmi, S. Stein, M. Beach, E. Pelayo, J.O. Maldonado, B.A. Lafont, S.I. Jang, N. Nasir, R.J. Padilla, V.A. Murrah, R. Maile, W. Lovell, S.M. Wallet, N.M. Bowman, S.L. Meinig, M.C. Wolfgang, S.N. Choudhury, M. Novotny, B.D. Aevermann, R.H. Scheuermann, G. Cannon, C.W. Anderson, R.E. Lee, J.T. Marchesan, M. Bush, M. Freire, A.J. Kimple, D.L. Herr, J. Rabin, A. Grazioli, S. Das, B.N. French, T. Pranzatelli, J.A. Chiorini, D.E. Kleiner, S. Pittaluga, S.M. Hewitt, P.D. Burbelo, D. Chertow, K. Frank, J. Lee, R.C. Boucher, S.A. Teichmann, B.M. Warner, and K.M. Byrd. 2021. SARS-CoV-2 infection of the oral cavity and saliva. Nature Medicine 27: 892-903. https://doi.org/10.1038/s41591-021-01296-8.

20. Ziegler, C.G.K., S.J. Allon, S.K. Nyquist, I.M. Mbano, V.N. Miao, C.N. Tzouanas, Y. Cao, A.S. Yousif, J. Bals, B.M. Hauser, J. Feldman, C. Muus, M.H. Wadsworth 2nd., S.W. Kazer, T.K. Hughes, B. Doran, G.J. Gatter, M. Vukovic, F. Taliaferro, B.E. Mead, Z. Guo, J.P. Wang, D. Gras, M. Plaisant, M. Ansari, I. Angelidis, H. Adler, J.M.S. Sucre, C.J. Taylor, B. Lin, A. Waghray, V. Mitsialis, D.F. Dwyer, K.M. Buchheit, J.A. Boyce, N.A. Barrett, T.M. Laidlaw, S.L. Carroll, L. Colonna, V. Tkachev, C.W. Peterson, A. Yu, H.B. Zheng, H.P. Gideon, C.G. Winchell, P.L. Lin, C.D. Bingle, S.B. Snapper, J.A. Kropski, F.J. Theis, H.B. Schiller, L.E. Zaragosi, P. Barbry, A. Leslie, H.P. Kiem, J.L. Flynn, S.M. Fortune, B. Berger, R.W. Finberg, L.S. Kean, M. Garber, A.G. Schmidt, D. Lingwood, A.K. Shalek, and J. Ordovas-Montanes. 2020. SARS-CoV-2 Receptor ACE2 Is an Interferon-Stimulated Gene in Human Airway Epithelial Cells and Is Detected in Specific Cell Subsets across Tissues. Cell 181: 1016-1035.e1019. https://doi.org/10.1016/j.cell.2020.04.035.

21. García-Ayllón, M.S., O. Moreno-Pérez, J. García-Arriaza, J.M. Ramos-Rincón, M.Á. Cortés-Gómez, G. Brinkmalm, M. Andrés, J.M. León-Ramírez, V. Boix, J. Gil, H. Zetterberg, M. Esteban, E. Merino, and J. Sáez-Valero. 2021. Plasma ACE2 species are differentially altered in COVID-19 patients. The FASEB Journal 35: e21745. https://doi.org/10.1096/fj.202100051R.

22. Grobe, N., M. Di Fulvio, N. Kashkari, H. Chodavarapu, H.K. Somineni, R. Singh, and K.M. Elased. 2015. Functional and molecular evidence for expression of the renin angiotensin system and ADAM17-mediated ACE2 shedding in COS7 cells. American Journal of Physiology. Cell Physiology 308: C767-777. https://doi. org/10.1152/ajpcell.00247.2014.

23. Guenterberg, K.D., V.P. Grignol, E.T. Raig, J.M. Zimmerer, A.N. Chan, F.M. Blaskovits, G.S. Young, G.J. Nuovo, B.L. Mundy, G.B. Lesinski, and W.E. Carson 3rd. 2010. Interleukin-29 binds 
to melanoma cells inducing Jak-STAT signal transduction and apoptosis. Molecular Cancer Therapeutics 9: 510-520. https:// doi.org/10.1158/1535-7163.Mct-09-0461.

24. Belgnaoui, S.M., S. Paz, and J. Hiscott. 2011. Orchestrating the interferon antiviral response through the mitochondrial antiviral signaling (MAVS) adapter. Current Opinion in Immunology 23: 564-572. https://doi.org/10.1016/j.coi.2011.08.001.

25. Patel, J.R., and A. Garcia-Sastre. 2014. Activation and regulation of pathogen sensor RIG-I. Cytokine \& Growth Factor Reviews 25: 513-523. https://doi.org/10.1016/j.cytogfr.2014.08.005.

26. Okada, H., and S. Murakami. 1998. Cytokine expression in periodontal health and disease. Critical Reviews in Oral Biology and Medicine 9: 248-266. https://doi.org/10.1177/10454411980090030101.

27. Wang, S.S., Y.L. Tang, X. Pang, M. Zheng, Y.J. Tang, and X.H. Liang. 2019. The maintenance of an oral epithelial barrier. Life Sciences 227: 129-136. https://doi.org/10.1016/j.lfs.2019.04.029.

28. Zheng, W., Q. Xu, Y. Zhang, and E, X., Gao, W., Zhang, M., Zhai, W., Rajkumar, R. S., Liu, Z. 2020. Toll-like receptor-mediated innate immunity against herpesviridae infection: A current perspective on viral infection signaling pathways. Virology Journal 17: 192. https://doi.org/10.1186/s12985-020-01463-2.

29. Sato, S., M. Sugiyama, M. Yamamoto, Y. Watanabe, T. Kawai, K. Takeda, and S. Akira. 2003. Toll/IL-1 receptor domain-containing adaptor inducing IFN-beta (TRIF) associates with TNF receptorassociated factor 6 and TANK-binding kinase 1, and activates two distinct transcription factors, NF-kappa B and IFN-regulatory factor-3, in the Toll-like receptor signaling. The Journal of Immunology 171: 4304-4310. https://doi.org/10.4049/jimmunol.171.8. 4304.

30. Mori, K., M. Yanagita, S. Hasegawa, M. Kubota, M. Yamashita, S. Yamada, M. Kitamura, and S. Murakami. 2015. Necrosis-induced TLR3 Activation Promotes TLR2 Expression in Gingival Cells. Journal of Dental Research 94: 1149-1157. https://doi.org/10. 1177/0022034515589289.

31. Teixeira, H., J. Zhao, D.F. Kinane, and M.R. Benakanakere. 2019. IFN-beta secretion is through TLR3 but not TLR4 in human gingival epithelial cells. Molecular Immunology 111: 27-31. https:// doi.org/10.1016/j.molimm.2019.03.006.

32. Prokunina-Olsson, L., N. Alphonse, R.E. Dickenson, J.E. Durbin, J.S. Glenn, R. Hartmann, S.V. Kotenko, H.M. Lazear, T.R, O'Brien, C. Odendall, O.O. Onabajo, H. Piontkivska, D.M. Santer, N.C. Reich, A. Wack, and I. Zanoni. 2020. COVID-19 and emerging viral infections: The case for interferon lambda. Journal of Experimental Medicine 217 https://doi.org/10.1084/jem.20200653.

33. Gibbs, S., and M. Ponec. 2000. Intrinsic regulation of differentiation markers in human epidermis, hard palate and buccal mucosa. Archives of Oral Biology 45: 149-158. https://doi.org/10.1016/ s0003-9969(99)00116-8.

34. Hosokawa, Y., I. Hosokawa, S. Shindo, K. Ozaki, and T. Matsuo. 2017. IL-29 Enhances CXCL10 Production in TNF-alpha-stimulated Human Oral Epithelial Cells. Immunological Investigations 46: 615624. https://doi.org/10.1080/08820139.2017.1336176.

35. Odendall, C., A.A. Voak, and J.C. Kagan. 2017. Type III IFNs Are Commonly Induced by Bacteria-Sensing TLRs and Reinforce Epithelial Barriers during Infection. The Journal of Immunology 199: 3270-3279. https://doi.org/10.4049/jimmunol.1700250.

36. Onabajo, O.O., A.R. Banday, M.L. Stanifer, W. Yan, A. Obajemu, D.M. Santer, O. Florez-Vargas, H. Piontkivska, J.M. Vargas, T.J. Ring, C. Kee, P. Doldan, D.L. Tyrrell, J.L. Mendoza, S. Boulant, and L. Prokunina-Olsson. 2020. Interferons and viruses induce a novel truncated ACE2 isoform and not the full-length SARS-CoV-2 receptor. Nature Genetics 52: 1283-1293. https://doi.org/10.1038/ s41588-020-00731-9.

37. Akira, S., S. Uematsu, and O. Takeuchi. 2006. Pathogen recognition and innate immunity. Cell 124: 783-801. https://doi.org/10. 1016/j.cell.2006.02.015.

38. Ermertcan, A.T., F. Öztürk, and K. Gündüz. 2011. Toll-like receptors and skin. Journal of the European Academy of Dermatology and Venereology 25: 997-1006. https://doi.org/10.1111/j.14683083.2011.04049.x.

39. Lai, Y., A. Di Nardo, T. Nakatsuji, A. Leichtle, Y. Yang, A.L. Cogen, Z.R. Wu, L.V. Hooper, R.R. Schmidt, S. von Aulock, K.A. Radek, C.M. Huang, A.F. Ryan, and R.L. Gallo. 2009. Commensal bacteria regulate Toll-like receptor 3-dependent inflammation after skin injury. Nature Medicine 15: 1377-1382. https://doi.org/10. 1038/nm.2062.

40. Bernard, J.J., C. Cowing-Zitron, T. Nakatsuji, B. Muehleisen, J. Muto, A.W. Borkowski, L. Martinez, E.L. Greidinger, B.D. Yu, and R.L. Gallo. 2012. Ultraviolet radiation damages self noncoding RNA and is detected by TLR3. Nature Medicine 18: 12861290. https://doi.org/10.1038/nm.2861.

41. Kato, H., O. Takeuchi, S. Sato, M. Yoneyama, M. Yamamoto, K. Matsui, S. Uematsu, A. Jung, T. Kawai, K.J. Ishii, O. Yamaguchi, K. Otsu, T. Tsujimura, C.S. Koh, and Reis e Sousa, C., Matsuura, Y., Fujita, T., Akira, S. 2006. Differential roles of MDA5 and RIG-I helicases in the recognition of RNA viruses. Nature 441: 101-105. https://doi.org/10.1038/nature04734.

42. Mukherjee, B., A. Bhattacharya, D. Bojkova, A.R. Mehdipour, D. Shin, K.S. Khan, H. Hei-Yin Cheung, K.B. Wong, W. Ng, J. Cinatl, P.P. Geurink, G.J. van der Heden van Noort, K. Rajalingam, S. Ciesek, G. Hummer, and I. Dikic. 2021. Famotidine inhibits Tolllike receptor 3-mediated inflammatory signaling in SARS-CoV2 infection. Journal of Biological Chemistry 100925 https://doi.org/ 10.1016/j.jbc.2021.100925.

43. Poeck, H., R. Besch, C. Maihoefer, M. Renn, D. Tormo, S.S. Morskaya, S. Kirschnek, E. Gaffal, J. Landsberg, J. Hellmuth, A. Schmidt, D. Anz, M. Bscheider, T. Schwerd, C. Berking, C. Bourquin, U. Kalinke, E. Kremmer, H. Kato, S. Akira, R. Meyers, G. Hacker, M. Neuenhahn, D. Busch, J. Ruland, S. Rothenfusser, M. Prinz, V. Hornung, S. Endres, T. Tuting, and G. Hartmann. 2008. 5'-Triphosphate-siRNA: Turning gene silencing and Rig-I activation against melanoma. Nature Medicine 14: 1256-1263. https://doi.org/10.1038/nm.1887.

44. Witte, E., G. Kokolakis, K. Witte, K. Warszawska, M. Friedrich, D. Christou, S. Kirsch, W. Sterry, H.D. Volk, R. Sabat, and K. Wolk. 2016. Interleukin-29 induces epithelial production of CXCR3A ligands and T-cell infiltration. Journal of Molecular Medicine (Berlin, Germany) 94: 391-400. https://doi.org/10.1007/ s00109-015-1367-y.

45. Jordan, W.J., J. Eskdale, M. Boniotto, M. Rodia, D. Kellner, and G. Gallagher. 2007. Modulation of the human cytokine response by interferon lambda-1 (IFN-lambda1/IL-29). Genes and Immunity 8: 13-20. https://doi.org/10.1038/sj.gene.6364348.

46. Kajita, A.I., S. Morizane, T. Takiguchi, T. Yamamoto, M. Yamada, and K. Iwatsuki. 2015. Interferon-Gamma Enhances TLR3 Expression and Anti-Viral Activity in Keratinocytes. The Journal of Investigative Dermatology 135: 2005-2011. https://doi.org/10. 1038/jid.2015.125

47. Zhang, S.Q., Z. Zhang, X. Luo, S. Yang, Y. Chai, H.L. Huang, X.Y. Yin, D.J. Hu, C.J. Yang, J.L. Liu, and X.J. Zhang. 2011. Interleukin 29 enhances expression of Toll receptor 3 and mediates antiviral signals in human keratinocytes. Inflammation Research 60: 1031-1037. https://doi.org/10.1007/s00011-011-0364-z. 
48. Wu, W., W. Zhang, E.S. Duggan, J.L. Booth, M.H. Zou, and J.P. Metcalf. 2015. RIG-I and TLR3 are both required for maximum interferon induction by influenza virus in human lung alveolar epithelial cells. Virology 482: 181-188. https://doi.org/10.1016/j. virol.2015.03.048.
Publisher's Note Springer Nature remains neutral with regard to jurisdictional claims in published maps and institutional affiliations. 